\title{
Physical and chemical characteristics of the longissimus dorsi from swine reared in climate-controlled and uncontrolled environments
}

\author{
Juliana Lolli Malagoli de Mello ${ }^{1}$ (D) Mariana Piatto Berton $^{1} \cdot$ Rita de Cassia Dourado $^{1}$. \\ Aline Giampietro-Ganeco ${ }^{1}$ - Rodrigo Alves de Souza ${ }^{1,2}$ • Fábio Borba Ferrari ${ }^{1}$ • \\ Pedro Alves de Souza ${ }^{1}$ - Hirasilva Borba ${ }^{1}$
}

Received: 29 July 2016 / Revised: 10 March 2017 / Accepted: 4 April 2017 /Published online: 20 April 2017 (C) ISB 2017

\begin{abstract}
The aim of this study was to evaluate the effect of ambient temperature on the physical and chemical characteristics of the longissimus dorsi muscle by comparing the quality of meat from pigs reared in a controlled and in an uncontrolled environment, the latter provided with a shallow pool. Twenty castrated male pigs of the Topigs line were randomly allotted to two treatments: a controlled environment, with constant temperature $\left(22^{\circ} \mathrm{C}\right)$ and relative humidity $(70 \%)$; and an uncontrolled environment in a conventional shed for rearing pigs equipped with a shallow pool, where pigs were subject to climatic variations. Meat from pigs kept in the controlled environment showed a greater capacity to retain intracellular water, higher tenderness, and lower cholesterol levels than meat from pigs reared in the uncontrolled environment, but displayed higher lipid oxidation and a lower concentration of DHA. Treatments had no effect on color, $\mathrm{pH}$, chemical composition, or fatty acid profile (except DHA concentration). Rearing pigs in sheds equipped with a shallow pool minimizes the effects of environmental heat on meat quality, allowing the production of high-quality meat in warm climate regions without expensive investments. Animals reared in an uncontrolled environment equipped with a shallow pool are able to produce
\end{abstract}

Juliana Lolli Malagoli de Mello julianalolli@zootecnista.com.br

Mariana Piatto Berton mapberton@gmail.com

1 Department of Technology, São Paulo State University-UNESP, Via de Acesso Professor Paulo Donato Castellane, s/n, Zona Rural, Jaboticabal, São Paulo 14884-900, Brazil

2 Department of Food Engineering, University of São Paulo-USP, Av. Duque de Caxias Norte, 225, Campus Fernando Costa-USP, CEP, Pirassununga, São Paulo 13635-900, Brazil meat with characteristics within the quality standards and with similar quality to that of meat from animals raised in controlled environment.

Keywords Ambience $\cdot$ Meat quality $\cdot$ Shallow pool . Thermoregulation

\section{Introduction}

The Brazilian pig farming activity has played an important role in the world market. To meet the growing demand for quantity and quality of swine meat, the productivity of national farming systems has increased, especially with the development of new technologies and improved knowledge about animal nutrition, physiology, and health. However, the thermal environment has often been disregarded, despite being a limiting factor to the production process (Manno et al. 2006).

Pigs are homeothermic animals that have an internal thermoregulatory system capable of maintaining body temperature and controlling homeothermy that is activated in case of unfavorable environmental conditions. Their growth performance is influenced by climatic changes, which, in certain seasons of the year, exceed the critical thresholds of animal thermal comfort (Kiefer et al. 2010). As the animals acquire a higher subcutaneous fat layer, they become unable to dissipate body heat, which complicates their adaptation to the tropical climate, characterized by high relative humidity and extreme temperature fluctuations (Rinaldo and Mourot 2001). The increased heat production resulting from a higher body weight indicates that the thermal requirements of pigs are lower during the grower and finisher stages. When the ambient temperature rises, the available energy is diverted as thermoregulatory mechanisms are activated (Kerr et al. 2003; Manno et al. 
2006) in an attempt to reach thermal equilibrium again, which changes the nutrient requirements of the animal. Growing pigs alter their behavior, physiological responses, and performance when subjected to high ambient temperatures (Kiefer et al. 2009), while pigs that have higher lean meat deposition rates are the most affected by high ambient temperatures (Paiano et al. 2007; Kiefer et al. 2010; Sarubbi et al. 2012).

According to the annual report of the Brazilian Association of Animal Protein (ABPA 2016), Brazil is listed fourth in the world ranking of pig farming, having produced 3.6 million tons of pork in 2015, and is the fourth largest exporter, though, only $15.2 \%$ of total production is exported. For the produced meat to be considered high quality by the consumer, aspects such as appearance, color, and exudate production are as important as taste and texture (Young et al. 2009). Information on any antemortem stress to which the animal is subjected can be obtained from the carcass (Shaw and Tume 1992; Ludtke et al. 2012). Stress results in behavioral and physiological responses that may contribute to a reduction of carcass yield and depreciation of meat quality (Kuchenmeister et al. 2002; Bench et al. 2008; Young et al. 2009; Ludtke et al. 2012).

When Berton et al. (2015) started this study by evaluating performance and carcass yield, they concluded that animals raised in an uncontrolled environment had a lower $(P<0.05)$ feed intake and poorer $(P<0.05)$ feed conversion than pigs raised in a controlled environment, but their weight gain was not affected $(P>0.05)$ by the treatments, suggesting that animals kept at room temperature, reared in sheds equipped with a shallow pool, perform better than those reared in a controlled environment. Animals raised in controlled and uncontrolled environments did not show differences $(P>0.05)$ regarding hot and cold carcass weights, carcass yield, and cooling loss. Also, no statistical difference was found with regard to carcass length, back fat thickness, and loin eye area.

This study thus proposed to evaluate the effect of ambient temperature on the physical and chemical characteristics of the longissimus dorsi muscle by comparing the quality of meat from pigs reared in a controlled and in an uncontrolled environment, the latter equipped with a shallow pool.

\section{Materials and methods}

\section{Sheds and animal management}

This study was conducted at the Laboratory of Animal Products Technology at the School of Agricultural and Veterinary Sciences (Faculdade de Ciências Agrárias e Veterinárias-FCAV) of UNESP, located in Jaboticabal, São Paulo, Brazil $\left(21^{\circ} 08^{\prime} \mathrm{S}, 48^{\circ} 11^{\prime} \mathrm{W}, 583 \mathrm{~m}\right.$ altitude). Pigs were reared in the Swine Sector of the Department of Animal Science at FCAV. Experimental protocols were reviewed and approved by the Ethics Committee for the Use of Animals of
São Paulo State University (Jaboticabal, São Paulo, Brazil), under no. 004633/13.

Twenty barrows $(n=20)$ of the Topigs line, acquired after weaning, at 21 days old, were randomly distributed into two groups. Ten animals $(n=10)$ were allotted to a shed with conditioned environment, named "controlled environment," characterized by constant temperature $\left(22^{\circ} \mathrm{C}\right)$ and humidity $(70 \%)$. The other ten animals $(n=10)$ were housed in a conventional shed for rearing pigs provided with a shallow pool, named "uncontrolled environment," where they were subjected to climatic variations. The conditioned shed was provided with nebulizers (Hidromotor HM250, with an air flow rate of $12,000 \mathrm{~m}^{3} / \mathrm{H}$ ), exhaust fans (Ventisol, with an air flow rate of $5000 \mathrm{~m}^{3} / \mathrm{h}$, power of $1 / 4 \mathrm{cv}, 1400 \mathrm{rpm}$, and $\left.50 / 60 \mathrm{~Hz}\right) 50 \mathrm{~cm}$ in diameter, and air conditioners (Split Springer, with a cooling capacity of 18,000 BTU), responsible for providing thermal comfort to animals in each rearing stage (grower and finisher) and renewing the oxygen in the environment. Sheds were equipped with digital thermohygrometers, installed at the average height of the body of the animals, to record the maximum and minimum temperatures and relative humidity inside the shed twice daily. Figure 1 describes the variation of minimum and maximum temperatures and air relative humidity in the uncontrolled environment. The minimum temperature was recorded between $6 \mathrm{~h} 00$ and $7 \mathrm{~h} 00$, while the maximum temperature was recorded between $18 \mathrm{~h} 00$ and $19 \mathrm{~h} 00$ throughout the experiment.

Pigs housed in the controlled environment were grouped in pairs in pens with concrete floor measuring $6 \mathrm{~m}^{2}$ with a height of $3.2 \mathrm{~m}$. Pigs housed in the uncontrolled environment were also grouped in pairs in pens with concrete floor with the same dimensions, but equipped with a shallow pool (1-m wide $\times$ 10 -cm deep). Pens in both sheds were separated by partitions that allowed pigs to see each other.

\section{Animal feeding}

Animals received different diets (grower and finisher, as described in Table 1) formulated according to the nutritional requirements for each rearing phase (Rostagno et al. 2005). Throughout the trial period, water and feed were provided ad libitum, using nipple drinkers and feeders.

\section{Slaughter and sample collection}

Because of the lack of differences in weight gain during the grower and finisher phases (Berton et al. 2015), animals from both studied groups could be slaughtered on the same day, at a body weight of $100 \mathrm{~kg}$, on average. Pigs raised in the controlled environment showed a carcass dressing percentage equal to $73.58 \%$ and a loin eye area (LEA) of $46.30 \mathrm{~cm}^{2}$, on average, while pigs raised in the uncontrolled environment 
Fig. 1 Variation of minimum and maximum temperatures and air relative humidity in the uncontrolled environment throughout the experiment, compared to temperature and humidity in the controlled environment

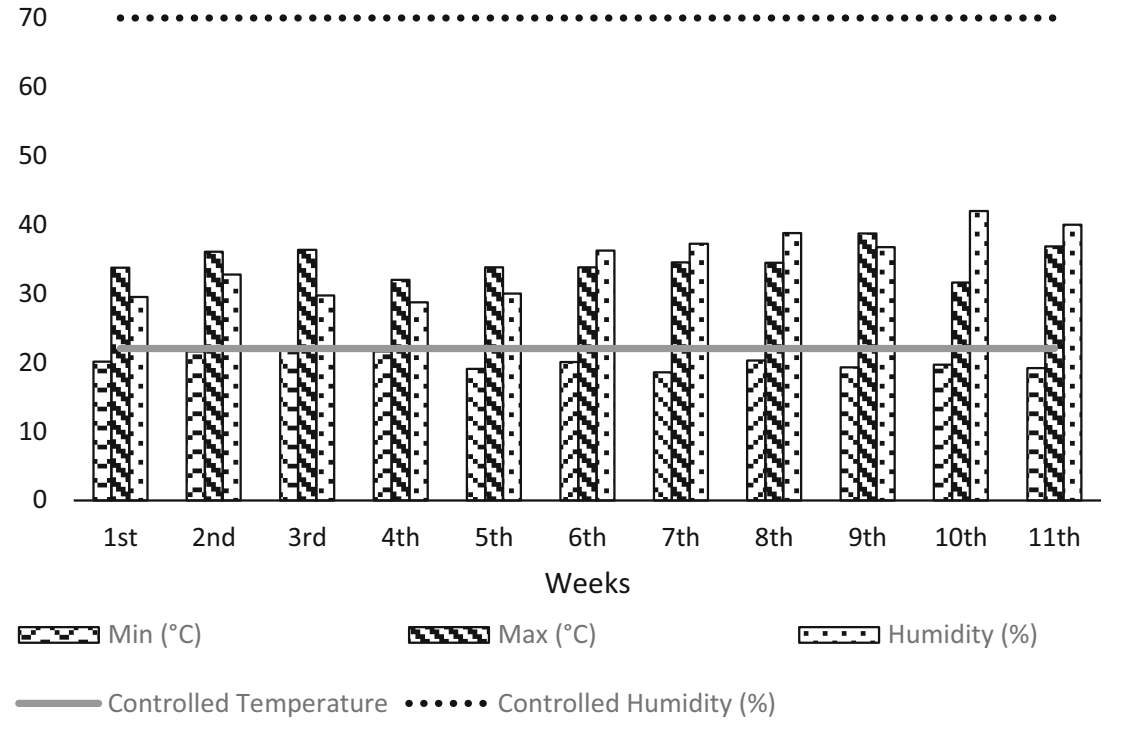

showed a carcass dressing percentage equal to $73.54 \%$ and a LEA of $43.00 \mathrm{~cm}^{2}$, on average (Berton et al. 2015).

Animals fasted for 12 and were sent to the Experimental Slaughterhouse of the University of São Paulo-USP, located in Pirassununga, São Paulo, Brazil (21 ${ }^{\circ} 59^{\prime} \mathrm{S}, 4^{\circ} 25^{\prime} \mathrm{W}, 627 \mathrm{~m}$ altitude), $142 \mathrm{~km}$ from the place where they were reared. Pigs were stunned with an electric shock of $220 \pm 20 \mathrm{~V}$ and $60 \mathrm{~Hz}$ frequency. After bleeding and cleaning, carcasses were chilled $\left(0 \pm 2{ }^{\circ} \mathrm{C}\right)$ for $24 \mathrm{~h}$. At 24 -h post-mortem, longissimus dorsi muscle samples were packed, labeled, and transported to the Laboratory of Animal Products Technology (FCAV/UNESP, Jaboticabal, São Paulo, Brazil) using a refrigerated vehicle for cold chain maintenance, for further physical and chemical analyses. The longissimus dorsi muscle samples were cut into 2.5 -cm-thick chops for the physical analysis. We evaluated color, at 24-h post-slaughter, and $\mathrm{pH}$, at 45-min post-slaughter and after $24 \mathrm{~h}$ under refrigeration, to determine changes during rigor mortis, which could characterize the occurrence of PSE (pale, soft, exudative) and DFD (dark, firm, dry) meat, water holding capacity, cooking loss, shear force, lipid oxidation, total cholesterol, and fatty acid profile.

\section{Methods}

Color ( $\mathrm{L}^{*}$ lightness; $\mathrm{a}^{*}$ redness; and $\mathrm{b}^{*}$ yellowness) was measured in three different regions of each sample (sample size equal to the loin eye area), using a Minolta CR-400 colorimeter (settings: diffuse illumination $/ 0^{\circ}$ viewing angle, illuminant D65, specular component included) calibrated to a white standard. The $\mathrm{pH}$ was measured in triplicate using a Testo 205 digital pH meter (Testo Inc., Sparta, NJ, USA) with a penetration electrode for direct insertion into the muscle. The $\mathrm{pH}$ assessments were carried out at 45-min post-slaughter, in three different regions of the loin eye area, immediately after the cross section in the left half of the carcass was made over the last rib. After $24 \mathrm{~h}$, the longissimus dorsi muscle was separated from the left half of the carcass and sliced in 2.5-cm-thick chops for immediate $\mathrm{pH}_{24 \mathrm{~h}}$ and color measurements. Water holding capacity was determined in triplicate according to the method proposed by Hamm (1961), using $2 \mathrm{~g}$ of boneless sample placed between two filter papers and acrylic plates that was subjected to the pressure of $10 \mathrm{~kg}$ for $5 \mathrm{~min}$. Water holding capacity was determined as the difference between initial and final weights, expressed in percentage terms.

Cooking loss was determined in two 2.5 -cm-thick chops from each animal, previously weighed on an analytical scale and cooked on a preheated grill (George Foreman GBZ80) until their internal temperature reached $71{ }^{\circ} \mathrm{C}$ (temperature controlled by thermocouples (Flyever Ind. e Com. de Equip. Eletr. Ltd., São Carlos, São Paulo, Brazil) individually inserted into each chop), according to the method proposed by Wheeler et al. (2005). Samples were cooled at room temperature and weighed again. The weight loss result was expressed as a percentage of exuded water in relation to the initial weight of the sample. After cooking loss analysis, samples were chilled overnight at $4{ }^{\circ} \mathrm{C}$. From each cooked sample, eight cylindrical subsamples, with known diameter $(1.27 \mathrm{~cm})$ and cut in the parallel direction to the muscle fibers, were obtained using a cutting blade adapted to a drill. Cylinders were placed with the fibers oriented perpendicularly to a Warner-Bratzler shear device coupled to a TA-XT2i texture analyzer (Stable Micro Systems, LTD., Godalming, UK) to determine shear force. The force required for shearing the samples was expressed in Newtons (N).

Lipid oxidation was studied by quantifying 2-thiobarbituric acid reactive substances (TBARS), following the method described by Vyncke (1970). Results were expressed in milligrams of malonaldehyde per kilogram of sample. Chemical composition was evaluated by determining the concentrations 
Table 1 Nutritional requirements of barrows with high genetic potential and regular performance

\begin{tabular}{|c|c|c|c|c|c|c|}
\hline Phase & \multicolumn{4}{|c|}{ Growing } & \multicolumn{2}{|l|}{ Finishing } \\
\hline Live weight, $\mathrm{kg}$ & \multicolumn{2}{|l|}{30 to 50} & \multicolumn{2}{|c|}{50 to 70} & \multicolumn{2}{|l|}{70 to 100} \\
\hline Feed intake, $\mathrm{kg} /$ day & \multicolumn{2}{|l|}{1.963} & \multicolumn{2}{|c|}{2.680} & \multicolumn{2}{|l|}{3.197} \\
\hline Digestible lysine requirement, g/day & \multicolumn{2}{|l|}{14.981} & \multicolumn{2}{|l|}{18.793} & \multicolumn{2}{|l|}{19.439} \\
\hline \multicolumn{7}{|l|}{ Nutrient } \\
\hline Metabolizable energy, Kcal/kg & \multicolumn{2}{|l|}{3230} & \multicolumn{2}{|l|}{3230} & \multicolumn{2}{|l|}{3230} \\
\hline Protein $(\%)$ & \multicolumn{2}{|l|}{15.80} & \multicolumn{2}{|l|}{14.30} & \multicolumn{2}{|l|}{12.71} \\
\hline Calcium (\%) & \multicolumn{2}{|l|}{0.631} & \multicolumn{2}{|l|}{0.551} & \multicolumn{2}{|l|}{0.484} \\
\hline Total phosphorus (\%) & \multicolumn{2}{|l|}{0.524} & \multicolumn{2}{|l|}{0.459} & \multicolumn{2}{|l|}{0.412} \\
\hline Available phosphorus (\%) & \multicolumn{2}{|l|}{0.332} & \multicolumn{2}{|l|}{0.282} & \multicolumn{2}{|l|}{0.248} \\
\hline Potassium (\%) & \multicolumn{2}{|l|}{0.448} & \multicolumn{2}{|l|}{0.425} & \multicolumn{2}{|l|}{0.400} \\
\hline Sodium $(\%)$ & \multicolumn{2}{|l|}{0.180} & \multicolumn{2}{|l|}{0.170} & \multicolumn{2}{|l|}{0.160} \\
\hline Chloride (\%) & 0.170 & & 0.160 & & 0.150 & \\
\hline Amino acid & Dig. & Total & Dig. & Total & Dig. & Total \\
\hline Lysine, (\%) & 0.758 & 0.861 & 0.696 & 0.692 & 0.609 & 0.692 \\
\hline Methionine (\%) & 0.227 & 0.250 & 0.209 & 0.229 & 0.189 & 0.208 \\
\hline Methionine + cystine $(\%)$ & 0.455 & 0.508 & 0.418 & 0.467 & 0.378 & 0.422 \\
\hline Triptfano (\%) & 0.136 & 0.155 & 0.125 & 0.143 & 0.116 & 0.132 \\
\hline Threonine $(\%)$ & 0.493 & 0.594 & 0.452 & 0.546 & 0.408 & 0.491 \\
\hline Arginine (\%) & 0.311 & 0.336 & 0.285 & 0.308 & 0.185 & 0.208 \\
\hline Valine $(\%)$ & 0.523 & 0.603 & 0.480 & 0.554 & 0.420 & 0.484 \\
\hline Isoleucine (\%) & 0.417 & 0.474 & 0.383 & 0.435 & 0.335 & 0.381 \\
\hline Leucine $(\%)$ & 0.758 & 0.836 & 0.696 & 0.767 & 0.609 & 0.671 \\
\hline Histidine (\%) & 0.250 & 0.276 & 0.230 & 0.253 & 0.201 & 0.221 \\
\hline Phenylalanine (\%) & 0.379 & 0.422 & 0.348 & 0.388 & 0.305 & 0.339 \\
\hline Phenylalanine + tyrosine $(\%)$ & 0.758 & 0.844 & 0.696 & 0.775 & 0.609 & 0.678 \\
\hline
\end{tabular}

The nutrient percentage was determined using digestible lysine requirements according to performance, amino acid/lysine ratio, and nutrient equations/Mcal.ME. Total lysine requirement was calculated considering the average true digestibility of lysine as $88 \%$ (Berton et al. 2015) of protein, fat, moisture, and ash, according to methods 977.14, 991.36, 950.46, and 920.153, respectively, recommended by AOAC (2005). Total cholesterol was quantified by the adaptation of the method proposed by Bohac et al. (1988). Ten grams of raw samples was subjected to lipid extraction using two portions of chloroform for each part methanol, followed by evaporation of the obtained chloroform extract with nitrogen gas and by saponification with a $12 \%$ alcoholic $\mathrm{KOH}$ solution. The fraction-containing cholesterol was extracted with $n$-hexane, purified, and subjected to color reaction with acetic acid, ferrous sulfate, and sulfuric acid. Total cholesterol concentration was determined in a spectrophotometer at $490 \mathrm{~nm}$. Fatty acids were isolated according to the method described by Bligh and Dyer (1959), and esterification was carried out following Maia and Rodriguez-Amaya (1993) using a Shimadzu 14B gas chromatograph (Shimadzu Corporation, Kyoto, Japan) equipped with a flame ionization detector and a fused silica capillary column (Omegawax 250) with $\mathrm{H}_{2}$ as the carrier gas. Peaks were identified by comparison with standards of known composition.

\section{Statistical analysis}

Data on $\mathrm{pH}$ were analyzed in a $2 \times 2$ completely randomized factorial arrangement (two rearing environments and analyses two times) and ten replicates, using the General Linear Models procedure of the Statistical Analysis System (SAS Institute Inc., 2002-2003). Other results were analyzed in a randomized complete design with two treatments (controlled environment and uncontrolled environment) and ten replicates. Data were analyzed using the one-way procedure of SAS software (SAS Institute Inc., 2002-2003) for analysis of variance (ANOVA) and, in case of significance, means were compared by Tukey's test, with significance set at $P<0.05$.

\section{Results and discussion}

\section{Meat color and $\mathrm{pH}$}

There was no difference $(P>0.05)$ between meat from swine raised in a controlled and uncontrolled environment (Table 2) 
for $\mathrm{L}^{*}, \mathrm{a}^{*}$, and $\mathrm{b}^{*}$, measured at $24 \mathrm{~h}$ after slaughter. Ambient temperature did not influence the $\mathrm{pH}$ of the longissimus dorsi muscle from pigs. After the establishment of rigor mortis $(24 \mathrm{~h}$ post-slaughter), $\mathrm{pH}$ declined from $6.51\left(\mathrm{pH}_{45 \mathrm{~m}}\right)$ to 5.49 $\left(\mathrm{pH}_{24 \mathrm{~h}}\right)$, reaching a range considered normal $(\mathrm{pH} 45 \mathrm{~m} \geq 5.8)$ for swine meat, as described by Bridi et al. (2009) and Caldara et al. (2012). By contrast, Rinaldo and Mourot (2001) studied the effects of tropical climate and season on the chemical composition and quality of swine meat and concluded that the $\mathrm{pH}_{24 \mathrm{~h}}$ of the longissimus dorsi muscle from pigs reared during the warm season (average temperature $27.9^{\circ} \mathrm{C}$ ) was higher than that of meat from pigs reared in a controlled environment (average temperature $20^{\circ} \mathrm{C}$ and $75 \% \mathrm{RH}$ ).

Paleness is caused by denaturation of sarcoplasmic proteins and myoglobin loss resulting from the $\mathrm{pH}$ decline that occurs post-mortem, and it increases the lightness of the meat surface (Ramos and Gomide 2007). Lightness is also influenced by the amount of water present on the meat surface (Kuo and Chu 2003), which depends on the water holding capacity. Meat classified as PSE has a lower ability to hold intracellular water, which, when flowing free in the tissue, reflects dispersed light and makes the meat lighter than what is considered normal. Caldara et al. (2012) stressed the difficulty classifying swine meat as normal, PSE, or DFD considering the meat color as an isolated factor, because the literature reports a wide variation for lightness values ( $\left.\mathrm{L}^{*}\right)$ considered normal; and that the final $\mathrm{pH}$ is not a good indicator of PSE condition, except when values are lower than 5.3. Channon et al. (2000) considered L* values as optimal for swine meat when below 53; the American Association of Meat Science (AMSA 2001) considered L* values between 49 and 60 as normal; Ramos and Gomide (2007), between 45 and 56; and Bridi et al. (2009), between 43 and 49 .

The pig meat color depends on the myoglobin concentration; on the relative amount of oxymyoglobin, metmyoglobin, and deoxymyoglobin (chemical forms of myoglobin); and on the muscle structure. It also depends on the dynamics and extent of the $\mathrm{pH}$ decline post-mortem and on the efficiency with which bleeding was performed (Karamucki et al. 2013). Some authors have stated that animals subjected to temperature variations can develop paler meat when compared with animals kept under constant temperatures (Gregory 2010; Van de Perre et al. 2010) and that high temperatures can increase the incidence of PSE meat (Lehotayová et al. 2012). Other researchers have affirmed that, in the summer, the occurrence of PSE meat is almost twice as common as that reported during the winter because pigs are sensitive to high temperatures and fluctuations in the ambient temperature that affect their ability to maintain body temperature, which results in stress, higher carcass temperatures postmortem, and poor-quality meat (Van de Perre et al. 2010). Thus, considering the color and $\mathrm{pH}$ values, regardless of the animal breeding environment, samples from this study may be considered within the standards of fresh pork meat.
Table 2 Mean values for lightness $\left(\mathrm{L}^{*}\right)$, redness $\left(\mathrm{a}^{*}\right)$, and yellowness $\left(\mathrm{b}^{*}\right)$, measured at $24 \mathrm{~h}$ after slaughter and $\mathrm{pH}$ measured at $45 \mathrm{~min}$ and $24 \mathrm{~h}$ after slaughter, of the longissimus dorsi muscle from swine reared in controlled and uncontrolled environments

\begin{tabular}{llll}
\hline Environment & $\mathrm{L}^{*}$ & $\mathrm{a}^{*}$ & $\mathrm{~b}^{*}$ \\
Controlled & 56.95 & 6.96 & 2.88 \\
Uncontrolled & 55.96 & 7.43 & 2.99 \\
$P$ value & 0.3634 & 0.2136 & 0.6644 \\
$\mathrm{CV}(\%)$ & 4.20 & 11.33 & 18.02
\end{tabular}

$\mathrm{pH}$

$\begin{array}{ll}\text { Environment (E) } & \\ \text { Controlled } & 6.02 \pm 0.57 \\ \text { Uncontrolled } & 5.98 \pm 0.51 \\ \text { Time }(T) & \\ 45 \mathrm{~min} & 6.51 \pm 0.20^{\mathrm{A}} \\ 24 \mathrm{~h} & 5.49 \pm 0.09^{\mathrm{B}} \\ P \text { value } & \\ P \text { value (E) } & 0.4000 \\ P \text { value }(T) & <0.0001 \\ P \text { value (int. ext) } & 0.0638 \\ \mathrm{CV}(\%) & 2.58\end{array}$

Means in the same column followed by different letters are significantly different by Tukey's test $(P<0.05)$

\section{Water holding capacity, cooking loss, shear force, and lipid oxidation}

Meat from pigs reared in the controlled environment showed higher $(P<0.05)$ water holding capacity than meat from pigs reared in the uncontrolled environment, which is an economically relevant result to the industry (Campanone et al. 2001), since a higher capacity to retain intracellular water means fewer losses during storage, processing, and marketing (Lawson 2004; Gomide et al. 2013; Oliveira et al. 2015) and better yield of the end product (Table 3 ).

Pigs reared in the controlled environment also had lower results for shear force of the longissimus dorsi muscle, which was more tender than the muscle from pigs reared in an uncontrolled environment. It is possible that the thermal stress due to environmental temperature variation led to a greater movement of animals reared in the uncontrolled environment, which might have triggered a reduction of meat tenderness in these animals due to increased physical activity. Iversen et al. (1995) suggested that a shear force of $60 \mathrm{~N}$ for swine meat is considered the acceptable limit of tenderness by the sensory panel, and values above $60 \mathrm{~N}$ characterize tough meat. Cooking loss was not influenced by the ambient temperature. Weight loss in meat from pigs reared in both treatments was considered normal, considering normal values in the range of 28 to $37 \%$ (Pereira 2012; Moura et al. 2015). 
Table 3 Mean values for water holding capacity (WHC), cooking loss (CL), shear force (SF), and lipid oxidation (TBARS) of the longissimus dorsi muscle from swine reared in controlled and uncontrolled environments

\begin{tabular}{lllll}
\hline Environment & WHC $(\%)$ & CL $(\%)$ & SF $(N)$ & TBARS $(m g$ MDA $/ k g)$ \\
\hline Controlled & $70.52 \pm 2.05^{\mathrm{A}}$ & $37.86 \pm 1.83$ & $27.99 \pm 3.47^{\mathrm{B}}$ & $0.175 \pm 0.050^{\mathrm{B}}$ \\
Uncontrolled & $66.70 \pm 2.74^{\mathrm{B}}$ & $35.27 \pm 4.14$ & $32.75 \pm 4.80^{\mathrm{A}}$ & $0.222 \pm 0.088^{\mathrm{A}}$ \\
$P$ value & 0.0024 & 0.0867 & 0.0018 & 0.0382 \\
CV $(\%)$ & 3.52 & 8.75 & 9.60 & 13.46 \\
\hline
\end{tabular}

Means in the same column followed by different letters are significantly different by Tukey's test $(P<0.05)$
Lipid oxidation is considered a major cause of deterioration of meat quality and meat products, whereby the development and formation of free radicals and other oxidized compounds such as cholesterol oxidation products (Morrissey et al. 1998; Ventanas et al. 2006) lead to changes in aroma and flavor (rancidity) (Lund et al. 2008; Spanos et al. 2016) that result in nutritional and sensory value losses (Zhang et al. 2013; Spanos et al. 2016). Nevertheless, lipid oxidation has positive implications, since some of the volatile compounds that give a pleasant taste to cured pork, for example, originate from the oxidation of unsaturated fatty acids (Carrapiso et al. 2002).

Oxidative phenomena in meat foods are initiated immediately after slaughter (or even during preslaughter) when cellular mechanisms that control oxidation no longer work (Morrissey et al. 1998; Ventanas et al. 2006). Free radicals are produced naturally in the animal body (Barreiros et al. 2006; Bezerra et al. 2015), in which around 2 to $5 \%$ of the oxygen consumed during a metabolic reaction is converted to free radicals (Falowo et al. 2014; Bezerra et al. 2015). Pig farming conditions, mainly those related to sheds, environment, and transport and genetics, influence free-radical production (Rossi et al. 2013, Bezerra et al. 2015), making the preslaughter management fundamental in the prevention of oxidative stress. Thus, pigs reared in the uncontrolled environment had a higher $(P<0.05)$ concentration of malonaldehyde (MDA) in the longissimus dorsi muscle than pigs reared in the controlled environment.

\section{Chemical composition}

The meat from the longissimus dorsi muscle of pigs reared in the controlled and uncontrolled environments had statistically similar levels of protein $(23.48 \%$, on average), fat (3.60\%, on average), moisture $(71.50 \%$, on average), and ash $(1.26$, on average) (Table 4), indicating that the shallow pool in the uncontrolled environment was as effective as the air conditioners in reducing the effects of temperature and relative humidity on the composition of the produced meat.

Intramuscular fat has positive effects on the sensory characteristics of the meat because it reduces the force required to shear the meat during chewing, making it more tender and juicier (Estévez et al. 2003). Unlike what was pointed out in our study, with special attention to the percentage of fat, Bragagnolo and Rodriguez-Amaya (2002) stated that the average chemical composition of swine meat consists of $72 \%$ moisture, $20 \%$ protein, $7 \%$ fat, $1 \%$ minerals, and less than $1 \%$ carbohydrates. Rinaldo and Mourot (2001) observed no effect on the chemical composition of the longissimus dorsi muscle from pigs reared under different environmental conditions, whose mean values for protein, fat, and moisture were 22.7, 1.9 , and $74.3 \%$, respectively, and the fat percentage was lower than that found in our study. Rinaldo and Le Dividich (1991) stated that a high ambient temperature $\left(31\right.$ to $\left.35^{\circ} \mathrm{C}\right)$ can slow the metabolism of the skeletal muscle and adipose tissue and change their chemical composition.

\section{Cholesterol and fatty acid profile}

The literature describes highly divergent cholesterol values that can range from $30 \mathrm{mg} / 100 \mathrm{~g}$ in pork to $114 \mathrm{mg} / 100 \mathrm{~g}$ in beef, and these differences can be attributed to the natural variation among the samples resulting from age, breed, feed, sex, anatomical location of the muscle, fat levels, rearing system and location, season of the year (Bragagnolo 2001), and the method of analysis itself (Bragagnolo and Rodriguez-Amaya 2002). In this study, pigs reared in the controlled environment had lower cholesterol levels $(24.61 \mathrm{mg} / 100 \mathrm{~g})$ in the longissimus dorsi muscle than pigs reared in the uncontrolled environment
Table 4 Chemical composition of the longissimus dorsi muscle from swine reared in controlled and uncontrolled environments

\begin{tabular}{lllll}
\hline Environment & Protein $(\%)^{\mathrm{a}}$ & Fat $(\%)^{\mathrm{a}}$ & Moisture (\%) & ${\text { Ash }(\%)^{\mathrm{a}}}^{\mathrm{a}}$ \\
\hline Controlled & $23.59 \pm 0.89$ & $3.63 \pm 0.75$ & $71.32 \pm 0.48$ & $1.28 \pm 0.05$ \\
Uncontrolled & $23.37 \pm 1.29$ & $3.57 \pm 0.57$ & $71.69 \pm 0.46$ & $1.25 \pm 0.07$ \\
$P$ value & 0.6542 & 0.8393 & 0.0941 & 0.3172 \\
CV $(\%)$ & 4.71 & 8.49 & 0.65 & 4.83 \\
\hline
\end{tabular}

${ }^{\mathrm{a}}$ Results expressed on a fresh matter basis 
(29.94 mg/100 g) (Table 5). Results obtained in our study are below the average values reported in the literature for cholesterol concentration in swine meat $(42-56 \mathrm{mg} / 100 \mathrm{~g}$, Bragagnolo 2001; 30 to $98 \mathrm{mg} / 100 \mathrm{~g}$, Bragagnolo and Rodriguez-Amaya 2002; 55 mg/100 g, TACO 2011). The cholesterol analysis method used in this study was compared with the gas chromatography method adopted by Bohac and Rhee (1988) and with high-performance liquid chromatography by Bragagnolo and Rodriguez-Amaya (2001); these researchers found no significant difference between the tested methods. The reasons for lower cholesterol levels in the longissimus

Table 5 Total cholesterol $(\mathrm{mg} / 100 \mathrm{~g})$ of the longissimus dorsi muscle and fatty acid composition (\% of total fatty acids) of fat from the longissimus dorsi muscle from swine reared in controlled and uncontrolled environments

\begin{tabular}{|c|c|c|c|c|}
\hline & Environment & & & \\
\hline Fatty acid & Controlled & Uncontrolled & $P$ value & $\mathrm{CV}(\%)$ \\
\hline Total cholesterol & $24.61 \pm 1.42^{\mathrm{B}}$ & $29.94 \pm 2.59^{\mathrm{A}}$ & $<0.0001$ & 7.65 \\
\hline SFA & $40.54 \pm 9.06$ & $41.06 \pm 916$ & 0.2719 & 2.56 \\
\hline MUFA & $50.33 \pm 14.59$ & $49.83 \pm 15.13$ & 0.5396 & 3.62 \\
\hline PUFA & $9.44 \pm 2.18$ & $9.14 \pm 2.18$ & 0.7449 & 22.37 \\
\hline C10:0 & $0.10 \pm 0.01$ & $0.11 \pm 0.01$ & 0.0500 & 8.99 \\
\hline C12:0 & $0.07 \pm 0.01$ & $0.08 \pm 0.01$ & 0.0541 & 7.09 \\
\hline $\mathrm{C} 14: 0$ & $1.33 \pm 0.05$ & $1.36 \pm 0.09$ & 0.3452 & 5.33 \\
\hline $\mathrm{C} 15: 0$ & $0.05 \pm 0.01$ & $0.05 \pm 0.01$ & 0.1597 & 21.13 \\
\hline C16:0 & $26.63 \pm 0.55$ & $26.87 \pm 0.89$ & 0.4711 & 2.76 \\
\hline $\mathrm{C} 17: 0$ & $0.27 \pm 0.09$ & $0.28 \pm 0.08$ & 0.7293 & 24.75 \\
\hline C18:0 & $11.92 \pm 0.45$ & $12.07 \pm 0.52$ & 0.4140 & 3.25 \\
\hline C20:0 & $0.11 \pm 0.06$ & $0.12 \pm 0.01$ & 0.6389 & 15.05 \\
\hline C16:1 & $3.41 \pm 0.41$ & $3.36 \pm 0.32$ & 0.6933 & 8.74 \\
\hline $\mathrm{C} 17: 1$ & $0.32 \pm 0.07$ & $0.29 \pm 0.07$ & 0.3024 & 23.40 \\
\hline $\mathrm{C} 18: 1 \oplus 9 \mathrm{c}$ & $41.97 \pm 1.88$ & $41.63 \pm 2.03$ & 0.6912 & 4.56 \\
\hline C18:1@7 & $3.90 \pm 0.18$ & $3.86 \pm 0.24$ & 0.6929 & 5.45 \\
\hline C20:1ळ9 & $0.62 \pm 0.14$ & $0.62 \pm 0.09$ & 0.9130 & 19.53 \\
\hline C24:1®9 & $0.06 \pm 0.03$ & $0.07 \pm 0.04$ & 0.3882 & 50.96 \\
\hline $\mathrm{C} 18: 2 \oplus 6 \mathrm{c}$ & $7.39 \pm 1.31$ & $7.15 \pm 1.72$ & 0.7272 & 21.00 \\
\hline C18:2c9.t11 & $0.06 \pm 0.01$ & $0.06 \pm 0.01$ & 0.1510 & 10.28 \\
\hline $\mathrm{C} 18: 3 \oplus 6$ & $0.07 \pm 0.01$ & $0.07 \pm 0.02$ & 0.3514 & 19.48 \\
\hline $\mathrm{C} 18: 3 \oplus 3$ & $0.18 \pm 0.02$ & $0.16 \pm 0.03$ & 0.1182 & 10.82 \\
\hline C20:2 & $0.21 \pm 0.04$ & $0.19 \pm 0.03$ & 0.3071 & 15.84 \\
\hline $\mathrm{C} 20: 3 \oplus 6$ & $0.15 \pm 0.04$ & $0.13 \pm 0.05$ & 0.2489 & 24.95 \\
\hline C20:4ø6 & $1.13 \pm 0.36$ & $1.08 \pm 0.46$ & 0.7748 & 37.69 \\
\hline $\mathrm{C} 20: 3 \oplus 3$ & $0.03 \pm 0.01$ & $0.02 \pm 0.01$ & 0.2790 & 23.56 \\
\hline $\mathrm{C} 20: 5 \oplus 3$ (EPA) & $0.02 \pm 0.004$ & $0.02 \pm 0.01$ & 0.0688 & 16.12 \\
\hline $\mathrm{C} 22: 4 \oplus 6$ & $0.18 \pm 0.06$ & $0.19 \pm 0.09$ & 0.8553 & 38.99 \\
\hline C22:6@3 (DHA) & $0.02 \pm 0.005^{\mathrm{B}}$ & $0.04 \pm 0.01^{\mathrm{A}}$ & $<0.0001$ & 13.88 \\
\hline
\end{tabular}

Means in the same row followed by different letters are significantly different by Tukey's test $(P<0.05)$

SFA saturated fatty acids, MUFA monounsaturated fatty acids, PUFA polyunsaturated fatty acids, EPA eicosapentaenoic acid, DHA docosahexaenoic acid dorsi muscle from pigs reared in controlled and uncontrolled environments are still unknown.

Regarding the fatty acid profile of fat contained in the longissimus dorsi muscle of the pigs, there was no difference $(P>0.05)$ between the studied treatments, except for DHA concentration $(\mathrm{C} 22: 6 \mathrm{n} 3)$, which indicates that climatic changes did not influence the concentration of fatty acids, or that the presence of shallow pool once again minimized the effects of temperature and relative humidity. Meat from pigs reared in the controlled environment showed 50\% less DHA than meat from pigs reared in the uncontrolled environment. The saturated fatty acids (SFA), monounsaturated fatty acids (MUFA), and polyunsaturated fatty acids (PUFA) concentrations from fat contained in the meat from pigs reared in both conditions proposed in this study were close to values described by Bragagnolo (2001) (38-42\% SFA, 42-46\% MUFA, and 12$16 \%$ PUFA) and close to results obtained by Bragagnolo and Rodriguez-Amaya (2002) and Hansen et al. (2006).

This study confirmed that the main fatty acids in pig meat are 18:1ø9, 16:0, 18:2ø6, 18:0, 16:1@7, and 18:1ळ7 (Bragagnolo and Rodriguez-Amaya 2002). These authors asserted that, in their study, these fatty acids accounted for approximately $94 \%$ of the total, but there are variations in concentration depending on the anatomical location of the muscle, and that pork loin has lower concentrations of fatty acids than ham and shoulder. In our experiment, the $₫ 6 / \infty 3$ ratio was 6.1 and 5.3 in meat from pigs reared in the controlled and uncontrolled environments, respectively, which is close to the maximum (4.0) recommended for the total diet.

Rinaldo and Mourot (2001) concluded that the environment influences the fatty acid composition of muscle lipids in the longissimus dorsi from pigs raised during warm and cold seasons and in a controlled environment. In a tropical climate during the warm season, the authors found an increase in the percentage of $\mathrm{C} 16: 1$ and $\mathrm{C} 18: 1$, while the percentage of C18:0 decreased. They also found that there was an increase in the concentration of MUFA when the animals were subjected to higher ambient temperatures. Estevez et al. (2003) studied the physical and chemical characteristics of the longissimus dorsi muscle from pigs reared in an extensive system compared with the characteristics of meat from commercial pigs and found that the concentrations of oleic (C18:1; $43.96 \%$, on average), palmitic (C16:0; $26.13 \%$, on average), and palmitoleic $(\mathrm{C} 16: 1 ; 4.8 \%$, on average) acids were higher $(P<0.001)$ in meat from animals reared in the extensive system than those found in meat from commercial pigs (36.41, 24.29, and 2.88\%, respectively). By contrast, the authors found that commercial pigs had higher proportions of polyunsaturated fatty acids (21.20\%), while the others had, on average, $10 \%$ PUFA.

In monogastric animals, the fatty acids from the feed are deposited directly into the tissues without chemical modifications (Bannon et al. 1988). Thus, by providing a diet rich in 
certain fatty acids important to human health, it is possible to enrich the lipid profile of pig meat. Note that, regardless of the influence of the rearing environment, the concentration of fatty acids in the carcass is highly correlated with the concentration of fatty acids in the animal diet (Rinaldo and Mourot 2001; Estévez et al. 2003).

\section{Conclusions}

Based on the conditions in which this study was undertaken, rearing pigs in sheds equipped with a shallow pool minimizes the effects of environmental heat on meat quality and provides a comfortable thermal environment similar to the controlled environment, thereby allowing the production of high-quality meat in warm climate regions without expensive investments. Although animals reared in ideal temperature and humidity conditions produce meat experimentally moister, more tender, and less prone to lipid oxidation, animals reared in an uncontrolled environment equipped with a shallow pool are also able to produce meat with characteristics within the quality standards and with similar quality to that of meat from animals raised in controlled environment.

Acknowledgments The authors thank São Paulo Research Foundation (Fundação de Amparo à Pesquisa do Estado de São Paulo-FAPESP, 2011/01643-7) for financial support.

\section{Compliance with ethical standards}

Ethical approval All procedures performed in this experiment complied with the ethical standards of the institution where they were conducted.

\section{References}

ABPA Brazilian Association of Animal Protein (2016) Annual report 2016. Available at http://abpa-br.com.br/storage/files/versao_final para_envio_digital_1925a_final_abpa_relatorio_anual_2016_ portugues_web1.pdf Accessed 16 july 2016

AMSA American Meat Science Association (2001) Meat evaluation handbook. Savoy, 2001

AOAC (2005) Official methods of analysis, 18th edn. Association of Analytical Chemists, Washington

Bannon CD, Craske JD, Norman LM (1988) Effect of overload of capillary gas-liquid chromatographic columns on the equivalent chain lengths of $\mathrm{C}_{18}$ unsaturated fatty acid methyl esters. J Chromatogr A 44:43-52

Barreiros ALBS, David JM, David JP (2006) Oxidative stress: relations between the formation of reactive species and the organism's defense. Quim Nov. 29:113-123

Bench C, Schaefer AL, Faucitano L (2008) The welfare of pigs during transport. In: Schaefer A, Faucitano L. Welfare of pigs - from birth to slaughter. Wageningen Academic Publishers, 2008, p.161-187.

Berton MP, Dourado RC, Lima FBF, Rodrigues ABB, Ferrari FB, Vieira LDC, Souza PA, Borba H (2015) Growing-finishing performance and carcass yield of pigs reared in a climate-controlled and uncontrolled environment. Int J Biometeorol 59:955-960

Bezerra BMO, Evangelista JNB, Nunes-Pinheiro DCS (2015) Impacts of oxidative stress in swine: challenges and perspectives. A review Rev Bras Hig San Anim 9(4):699-715

Bligh GE, Dyer JW (1959) A rapid method of total lipid extraction and purification. Can J Biochem Physiol 37:911-917

Bohac CE, Rhee KS, Cross HR, Ono K (1988) Assessment of methodologies for colorimetric cholesterol assay of meats. J Food Sci 53: 1642-1693

Bohac CE, Rhee KS (1988) Influence of animal diet and muscle location on cholesterol content of beef and pork muscles. Meat Sci 23:71-75

Bragagnolo N (2001) Aspectos comparativos entre carnes segundo a composição de ácidos graxos e teor de colesterol. In: $2^{\mathrm{a}}$ Conferência Internacional Virtual sobre Qualidade de Carne Suína, Santa Catarina. Concórdia, Brasil. Available at http://www.cnpsa. embrapa.br/sgc/sgc_publicacoes/anais01cv2_bragagnolo_pt.pdf Accessed 17 july 2016

Bragagnolo N, Rodriguez-Amaya DB (2001) Determinação de colesterol em carnes: comparação de um método colorimétrico e um método por cromatografia líquida de alta eficiência. Rev Inst Adolfo Lutz 60:53-57

Bragagnolo N, Rodriguez-Amaya DB (2002) Cholesterol, total lipds and fatty acids in cuts of pork. Ciênc Tecnol Aliment 22(1):98-1043

Bridi AM, Silva CA (2009) In: Ana Maria Bridi; Caio Abércio da Silva. (Org.). Avaliação da Carne Suína. 1 ed. Londrina: Midiograf, 2009, volume 1, p. 17-30 Capítulo de Livro

Caldara FR, Santos VMO, Santiago JC, Almeida Paz ICL, Garcia RG, Vargas Junior FM, Santos LS, Nääs IA (2012) Physical and sensory properties of PSE pork. Rev Bras Saúde Prod Anim 13(3):815-824

Campañone LA, Salvadori VO, Mascheroni RH (2001) Weight loss during freezing and storage of unpackaged foods. J Food Eng 47:69-79

Carrapiso AI, Ventanas J, Garcia C (2002) Characterization of the most odor active compounds of Iberian ham headspace. J Agric Food Chem 50:1996-2000

Channon HA, Payne AM, Warner RD (2000) Halothane genotype, preslaughter handling and stunning method all influence pork quality. Meat Sci 56(3):291-299

Estévez M, Morcuende D, López RC (2003) Physico-chemical characteristics of M. Longissimus dorsi from three lines of free-range reared Iberian pigs slaughtered at $90 \mathrm{~kg}$ live-weight and commercial pigs: a comparative study. Meat Sci 64:499-506

Falowo AB, Fayemi PO, Muchenje V (2014) Natural antioxidants against lipid-protein oxidative deterioration in meat and meat products: a review. Food Res Int 64:171-181

Gomide LAM, Ramos EM, Fontes PR (2013) A carne como alimento; Propriedades da carne fresca. In: Ciência e qualidade da carne: fundamentos. Universidade Federal de Viçosa, Viçosa, p 155

Gregory NG (2010) How climatic changes could affect meat quality. Food Res Int 43(7):1866-1873

Hamm R (1961) Biochemistry of meat hydratation. Adv Food Res 10: 355-463

Hansen LL, Claudi-Magnussen C, Jensen SK, Andersen HJ (2006) Effect of organic pig production systems on performance and meat quality. Meat Sci 74:605-615

Iversen P, Henckel P, Larsen LM, Monllao S, Møller AJ (1995) Tenderisation of pork as affected by degree of cold-induced shortening. Meat Sci 40:171-181

Karamucki T, Jakubowska M, Rybarczyk A, Gardzielewska J (2013) The influence of myoglobin on the colour of minced pork loin. Meat Sci 94:234-238

Kerr BJ, Yen JT, Nienaber JA, Easter RA (2003) Influences of dietary protein level, amino acid supplementation and environment temperature on performance, body composition, organ weights and total heat production of growing pigs. J Anim Sci 81:1998-2007 
Kiefer C, Meignen BCG, Sanches JF, Carrijo AS (2009) Response of growing swine maintained in different thermal environments. Arch Zootec 58(221):55-64

Kiefer C, Moura MS, Silva EA, Santos AP, Silva CM, Luz MF, Nantes CL (2010) Response of finishing swine maintained in different thermal environments. Rev Bras Saúde Prod An 11(2):496-504

Küchenmeister U, Kuhn G, Stabenow B, Ender K (2002) The effect of experimental stress on sarcoplasmic reticulum $\mathrm{Ca} 2+$ transport and meat quality in pig muscle. Meat Sci 61(4):375-380

Kuo CC, Chu CY (2003) Quality characteristics of Chinese sausages made from PSE pork. Meat Sci 64(4):441-449

Lawson MA (2004) The role of integrin degradation in post-mortem drip loss in pork. Meat Sci 68:559-566

Lehotayová A, Bučko O, Petrák J, Mrázová J, Debrecéni O (2012) Effect of high ambient temperature on meat quality of pigs. Res pig breed, available at http://www.Respigbreed.Cz/2012/2/8.Pdf Accessed 17 july 2016

Ludtke CB, Costa OAD, Roça RO, Silveira ETF, Athayde NB, Araújo AP, Mello Junior A, Azambuja NC (2012) Animal welfare at preslaughter handling and the influence on pork meat quality and on stress physiological parameters. Cienc Rural 42(3):532-537

Lund MN, Christensen M, Fregil L, Hviid MS, Skibsted LH (2008) Effect of high-oxygen atmosphere packaging on mechanical properties of single muscle fibres from bovine and porcine longissimus dorsi. Eur Food Res Technol 227(5):1323-1328

Maia EL, Rodriguez-Amaya DB (1993) Avaliação de um método simples e econômico para metilação de ácidos graxos de lipídeos de diversas espécies de peixes. Rev Inst Adolfo Lutz 53:27-35

Manno MC, Oliveira RFM, Donzele JL, Oliveira WP, Vaz RGMV, Silva BAN, Saraiva EP, Lima KRS (2006) Efeitos da temperatura ambiente sobre o desempenho de suínos dos 30 aos $60 \mathrm{~kg}$. R Bras Zootec 35(2):471-477

Morrissey PA, Sheehy PJA, Galvin K, Kerry JP, Buckley DJ (1998) Lipid stability in meat and meat products. Meat Sci 49:73-86

Moura JWF, Medeiros FM, Alves MGM, Batista ASM (2015) Fatores influenciadores na qualidade da carne suína. Rev Cient Prod Anim 17(1):18-29

Oliveira FR, Boari CA, Pires AV, Mognato JC, Carvalho RMS, Santos Junior MA, Mattioli CC (2015) Pre slaughter fasting and free-range broilers meat quality. Rev Bras Saúde Prod Anim 16:667-677

Paiano D, Barbosa OR, Moreira I, Quadros ARB, Silva MAA, Oliveira CAL (2007) Behavior of pigs kept in partially slotted floor or shallow pool pens. Acta Scient Anim Sci 29(3):345-351

Pereira LA (2012) Estudo comparativo de técnica de determinação da força de cisalhamento de carne. 2012 71f. Dissertação (Mestrado em Engenharia de Alimentos)-Universidade de São Paulo, Pirassununga

Ramos EM, Gomide LAM (2007) Avaliação de carnes anormais: condições PSE e DFD. In: Avaliação da qualidade de carnes: Fundamentos e metodologias. Ed. UFV, Viçosa, pp 531-575
Rinaldo D, Le Dividich J (1991) Effects of warm exposure on adipose tissue and muscle metabolism in growing pigs. Comp Biochem Physiol 100:995-1002

Rinaldo D, Mourot J (2001) Effects of tropical climate and season on growth, chemical composition of muscle and adipose tissue and meat quality in pigs. Anim Res 50(6):507-521

Rossi R, Pastorelli G, Corino C (2013) Application of KRL test to assess total antioxidante activity in pigs: sensitivity to dietary antioxidants. Res Vet Sci 94:372-377

Rostagno HS, Albino LFT, Donzele JL, Gomes PC, de Oliveira RF, Lopes DC, Ferreira AS, de Barreto SLT (2005) Tabelas brasileiras para aves e suínos: composição de alimentos e exigências nutricionais, 2nd edn. Editora UFV, Viçosa, MG, $186 \mathrm{p}$

Sarubbi J, Rossi LA, Moura DJ, Oliveira R, Maia APA (2012) Nocturnal thermal comfort in facilities for growing swines. Eng Agríc 32(6): 1034-1040

SAS Statistical Analysis System 2002 SAS version 9.1. (SAS Institute Inc.: Cary, NC)

Shaw FD, Tume RK (1992) The assessment of pre-slaughter and slaughter treatments of livestock by measurement of plasma constituentsa review of recent work. Meat Sci 32(3):311-329

Spanos D, Tørngren MA, Christensen M, Baron CP (2016) Effect of oxygen level on the oxidative stability of two different retail pork products stored using modified atmosphere packaging (MAP). Meat Sci 113:162-169

TACO (2011) Tabela brasileira de composição de alimentos Available at http://www.unicamp.br/nepa/taco/contar/taco 4 edicao ampliada e_revisada.pdf?arquivo=taco_4_versao_ampliada_e_revisada.pdf Accessed 21 July 2016

Van De Perre V, Permentier L, De Bie S, Verbeke G, Geers R (2010) Effect of unloading, lairage, pig handling, stunning and season on pH of pork. Meat Sci 86:931-937

Ventanas S, Estevez M, Tejeda JF, Ruiz J (2006) Protein and lipid oxidation in longissimus dorsi and dry cured loin from Iberian pigs as affected by crossbreeding and diet. Meat Sci 72:647-655

Vyncke BW (1970) Direct determination of the thiobarbituric acid value in trichloracetic acid extracts of fish as a measure of oxidative rancidity. Fette Seifen Anstrichm Leinfelden 72:1084-1087

Young JF, Bertram HC, Oksbjerg N (2009) Rest before slaughter ameliorates pre-slaughter stress-induced increased drip loss but not stressinduced increase in the toughness of pork. Meat Sci 83:634-641

Wheeler TL, Shackelford SD, Koohmaraie M (2005) Shear force procedures for meat tenderness measurement. United States Department of Agriculture (USDA), Clay Center, NE (2005), p. 7 (A. R. Service, Trans.).

Zhang W, Xiao S, Ahn DU (2013) Protein oxidation: basic principles and implications for meat quality. Crit Rev Food Sci Nutr 53(11):11911201 